\title{
Elective cesarean section on maternal request: ethical and legal considerations
}

\author{
Claudia Casella', Emanuele Capasso' (iD , Cristina Bianco' (iD), Gabriele Saccone² (iD, \\ Maurizio Guida², Vincenzo Graziano', Mariano Paternoster ${ }^{1}$ \\ ${ }^{1}$ Department of Law, University of Naples Federico II, Naples, Italy \\ ${ }^{2}$ Department of Neuroscience, Reproductive Sciences and Dentistry, School of Medicine, University of Naples Federico II, Naples, Italy
}

\begin{abstract}
Cesarean is defined as the delivery of a fetus through surgical incisions made through the uterine wall. Primary cesarean sections often lead to repeat cesareans, which may lead to placenta accreta spectrum disorders. The ethic of exposing mothers to these risks, as well as performing surgery on what is otherwise a healthy patient, become entangled with the demand for patient choice, as well as the increasing financial strain on our healthcare system. The main question to be examined is whether it is ethical to allow women to opt for cesarean delivery in the absence of obstetric indication (i.e. cesarean delivery on maternal request), taking into account the increased risk to the mother and her future offspring.
\end{abstract}

Keywords: Caesarean section, legal, placenta accreta, previa, law.

Cesarean delivery is defined as the delivery of a fetus through surgical incisions made through the abdominal wall (laparotomy) and the uterine wall (hysterotomy). The overall annual incidence rate of caesarean section in the United States has been steadily rising since 1996, reaching $32 \%$ in the 2018 . Primary cesarean sections often lead to repeat cesareans, which may lead to placenta accreta spectrum disorders. If primary and secondary cesarean rates continue to rise as they have in recent years, by 2021 the cesarean section rate will be $56.2 \%$, and there will be an additional 6236 placenta previas, 4504 placenta accretas, and 130 maternal deaths annually. The rise in these complications will lag behind the rise in cesareans by approximately 6 years.
Özet: Maternal talep üzerine elektif sezaryen: Etik ve yasal hususlar

Sezaryen, uterus duvarında yapılan cerrahi insizyonlar aracılı̆̆ıyla fetüsün doğurtulması olarak tanımlanmaktadır. Primer sezaryen operasyonları genellikle tekrarlayan sezaryenlere sebep olmakta ve bu da plasenta akreta spektrum bozukluklarına yol açabilmektedir. Sağlıklı bir hastanın üzerinde cerrahi işlem uygulamanın yanı sıra gebeleri bu risklere maruz bırakma konusundaki etik tutum, sağlık sistemimiz üzerinde artan mali baskıyla beraber hasta tercihine yönelik talep ile daha da karmaşık hale gelmiştir. Ele alınacak asıl soru, annenin ve doğacak bebeğinin artmış riskini dikkate alarak, obstetrik endikasyon yokken gebelerin sezaryen doğumu seçmesine izin vermenin (ör. maternal talep üzerine sezaryen doğum) etik olup olmadığıdır.

Anahtar sözcükler: Sezaryen, hukuk, plasenta akreta, previa, yasa.

In Italy, a huge increase in the rate of cesarean delivery has been noticed, from $13.3 \%$ in the 1981 to $33.16 \%$ in the 2018 , mostly in the southern parts of Italy, with a $40.82 \%$ rate in Puglia and $53.14 \%$ rate in Campania region. Italy is now the European country with the highest rate of cesarean section. Lastly, major differences were registered in the same region, between different birth centers, with cesarean section rate substantially higher than the national average in Units with a low number of deliveries and in private structures. ${ }^{[1]}$ Maternal factors associated with a higher request for cesarean delivery in Italy were: age, nulliparity, lower education and a previous cesarean section. $^{[2]}$

Correspondence: Gabriele Saccone, MD. Department of Neuroscience, Reproductive Sciences and Dentistry, School of Medicine, University of Naples Federico II, Naples, Italy. e-mail: gabriele.saccone.1990@gmail.com / Received: August 9, 2020; Accepted: September 14, 2020

Please cite this article as: Casella C, Capasso E, Bianco C, Saccone G, Guida M, Graziano V, Paternoster M. Elective cesarean section on maternal request: ethical and legal considerations. Perinatal Journal 2020;28(3):154-156. doi:10.2399/prn.20.0283007 
Cesarean delivery data contradict the indications of the World Health Organization (WHO) which established a limit of $15 \%$ rate. ${ }^{[3]}$ This suggests that in Italy there is a general policy to favor cesarean sections without a true indication. Probably this happens for relief of legal pressure ${ }^{[4]}$ and/or to avoid maternal pain or discomfort, and for childbirth fear.

Cesarean section is as a safer method of delivery in situations such as twin pregnancies or breech presentation as well as when a fetus shows signs of distress. Nonetheless, cesarean delivery is always associated with increased risk in future pregnancies, and with intraoperative and postoperative complications. These risk may not be fully understood by the women.

The ethic of exposing mothers to these risks, as well as performing surgery on what is otherwise a healthy patient, become entangled with the demand for patient choice, as well as the increasing financial strain on our healthcare system. The main question to be examined is whether it is ethical to allow women to opt for cesarean delivery in the absence of obstetric indication (i.e. cesarean delivery on maternal request), taking into account the increased risk to the mother and her future offspring.

The American College of Obstetricians and Gynecologists (ACOG) published a Committee Opinion statement on the basis of which the obstetrician, if consider not necessary the claim of doing a cesarean section on maternal request, can refrain from the request of proceeding and direct the woman to another doctor. When the obstetrician decides to provide the cesarean delivery, s/he has to warn the patient on eventual risks and the benefits of the operation compared to vaginal delivery respecting the ethical principles of autonomy, beneficence, nonmaleficence, veracity and justice. ${ }^{[5]}$

The Royal College of Obstetricians and Gynaecologists (RCOG) put forward the following recommendations: ${ }^{[6]}$

- Maternal request is not on its own an indication for cesarean delivery and specific reasons for the request should be explored, discussed and recorded.

- When a woman requests a cesarean delivery in the absence of an identifiable reason, the overall benefits and risks of cesarean delivery compared with vaginal birth should be discussed and recorded.

- When a woman requests a cesarean delivery because she has a fear of childbirth, she should be offered counselling (such as cognitive behavioral therapy) to help her to address her fears in a supportive manner, because this results in reduced fear of pain in labor and shorter labor.

- An individual clinician has the right to decline a request for cesarean delivery in the absence of an identifiable reason. However, the woman's decision should be respected and she should be offered referral for a second opinion.

- In 2012, a Cochrane review aimed to assess the effects on perinatal and maternal morbidity and mortality, and on maternal psychological morbidity, of planned caesarean delivery versus planned vaginal birth in women with no clear clinical indication for caesarean section. The review concluded that there is no evidence from randomized controlled trials, upon which to base any practice recommendations regarding planned caesarean section for non-medical reasons at term. ${ }^{[7]}$

More recently, the ACOG revised the Committee Opinion on Cesarean Delivery on Maternal Request and made the following recommendations: ${ }^{[8]}$

- If a patient's main motivation to opt for a cesarean delivery is the fear of pain in childbirth, obstetricians should discuss and offer analgesia, as well as prenatal childbirth education and emotional support during labor.

- In the absence of maternal or fetal indications for cesarean delivery, a plan for vaginal delivery is safe and appropriate and should be recommended.

- After exploring the reasons behind the patient's request and discussing the risks and benefits, cesarean delivery on maternal request should not be performed before 39 weeks of gestation. Also, women should be informed of the risk of placenta previa and postpartum hysterectomy in the subsequent pregnancies. In Italy practice guidelines from the Ministry of Health, aiming to reduce the cesarean section rate, suggest attenuating the fear of childbirth, providing counseling about the medical issues of labor, eventually addressing the patient to another physician for obtaining a second opinion. ${ }^{[8]}$

Essentially, the increasing rate of cesarean delivery on maternal request with no medical indication comes from two reasons: the maternal presumption of preventing adverse events for the newborn, and the providers fear of liability for medical malpractice. Two different considerations have to be made from an ethical point of view: The obstetrician may have to respect the right of 
the mother to refuse vaginal delivery (e.g. for fear of labor pain) and opt for cesarean section or the obstetrician has the right to refuse the cesarean delivery if not necessary. In our opinion, concern about labor pain and discomfort, or about fear of neonatal adverse outcomes, are not sufficient to admit a strong and conscious determination to the cesarean delivery. Moreover, when this occurs when the woman is laboring, pain and fear may have a huge impact on her decisional power. In this exact context the obstetrician has to offer support to the patient, and may have to operate an adequate verification of her actual willing. It was observed, however, that psychological support during pregnancy may be beneficial to women who have fear of vaginal delivery, as well as to those who had a prior negative childbirth experience. ${ }^{[9,10]}$

However, in our opinion, in the assumption of a conflict between the right of self-determination of the patient and the respect of the obstetrician professional autonomy, the patient position should be privileged. In this context, the circumstances in which a patient voluntarily requests a cesarean section are also decisive. If the refusal of the obstetrician does not result in immediate harm to the patient, the principle of responsible scientific freedom of the medical profession should be respected. Otherwise, if there is no possibility to delegate the medical service to other doctors, this principle must be sacrificed to the benefit and willing of the woman. Moreover, the consent of the pregnant woman should derive from a basic information provided as early as possible in the antenatal period, and repeated with each change in the intended care path. Using this method there is enough time to talk about women's concerns and wishes, and to arrange appointments with other healthcare providers, who may be able to help, when there are no urgent matters capable of influencing the choices, and when it is generally possible to deal calmly with all the issues of decision. In this sense, we believe that the RCOG opinion "Choosing to have a caesarean section" may be very useful for pregnant women who wish to have a planned cesarean delivery. ${ }^{[6]}$

Conflicts of Interest: No conflicts declared.

\section{References}

1. Yearly report on the activity of hospitalization. Data SDO 2018. [Internet]. Rome: General Direction of Health Planning. [2019 June]. Available from: http://www.salute.gov.it/imgs/ C_17_pubblicazioni_2898_allegato.pdf

2. Torloni MR, Betrán AP, Montilla P, Scolaro E, Seuc A, Mazzoni A, et al. Do Italian women prefer cesarean section? Results from a survey on mode of delivery preferences. BMC Pregnancy Childbirth 2013;13:78. [PubMed] [CrossRef]

3. Maternal \& Child Health Research Consortium. Confidential enquity into stillbirths and deaths in infants. 7th Annual Report, 41, London: MCHRC; 2000.

4. Vimercati A, Greco P, Kardashi A, Rossi C, Loizzi V, Scioscia $\mathrm{M}$, et al. Choice of cesarean section and perception of legal pressure. J Perinat Med 2000;28:111-7. [PubMed] [CrossRef]

5. American College of Obstetricians and Gynecologists. Surgery and patient choice: the ethics of decision making [ACOG Committee Opinion no 289] Obstet Gynecol 2003; 102:1101-6. [PubMed] [CrossRef]

6. National Collaborating Centre for Women's and Children's Health. Caesarean section. Clinical Guideline. April 2004. http://www.csh.org.tw/dr.tcj/Educartion/Guideline/OB\%20g uideline/CS1\%20Guideline.pdf

7. Lavender T, Hofmeyr GJ, Neilson JP, Kingdon C, Gyte GML. Caesarean section for non-medical reasons at term. Cochrane Database Syst Rev 2012;2012(3):CD004660. [PubMed] [CrossRef]

8. The American College of Obstetricians and Gynecologists (ACOG). ACOG Committee Opinion No. 761: Cesarean delivery on maternal request. Obstet Gynecol 2019;133:e73e7. [PubMed] [CrossRef]

9. González-Hernando CRN, García-Alonso MM, VázquezFernández ME, San José-Arribas A, Sanz-Almazán M, PueblaNicolás E. Evaluation of a "Mother and Child Healthcare Blog" and post-use satisfaction: a qualitative interview study. International Journal of Nursing 2016;3:1-8. [CrossRef]

10. Nanette PF, Cordero MAW, Munoz AP, Nash D. Collaboration effort between physicians and nurses: a feedback tool for the review of the hospitals. International Journal of Nursing 2017;4:19-26. [CrossRef]

Bu makalenin kullanım izni Creative Commons Attribution-NoCommercial-NoDerivs 3.0 Unported (CC BY-NC-ND3.0) lisansı aracılı̆̆ıyla bedelsiz sunulmaktadır. / This work is licensed under the Creative Commons Attribution-NonCommercial-NoDerivs 3.0 Unported (CC BY-NC-ND3.0) License. To view a copy of this license, visit http://creativecommons.org/licenses/by-nc-nd/3.0/ or send a letter to Creative Commons, PO Box 1866 , Mountain View, CA 94042, USA. 